\title{
Samostanowienie i integracja społeczno-zawodowa dorosłych osób z niepełnosprawnością na przykładzie zastosowania programu Centrum Wspierania Edukacji Zawodowej (PACE) w USA
}

\section{Wprowadzenie}

Każdy człowiek doświadcza codziennie wielu sytuacji wymagających od niego podejmowania autonomicznych decyzji. Poczucie sprawowania kontroli nad swoim życiem, decydowania o nim i możliwości osiągania swoich celów życiowych bez zbędnych nacisków zewnętrznych stanowi ważną wartość w życiu wszystkich osób, w tym także osób z niepełnosprawnością. Prawo do samostanowienia, do samodzielności i niezależności, do uznania podmiotowości osoby i poszanowania dokonywanych przez nią wyborów powinno być w pełni realizowane poprzez umożliwienie jej kierowania własnym zachowaniem i kształtowania relacji społecznych opartych na zasadzie wzajemności. Niestety, u osób z niepełnosprawnością można 
220 zaobserwować nadmierne uzależnienie od innych ludzi, które jest widoczne w wielu dziedzinach codziennego funkcjonowania ${ }^{1}$.

\section{Samostanowienie osób z niepełnosprawnością}

Jedną z cech, które różnią osoby z niepełnosprawnością od osób w pełni sprawnych, jest zdolność do samostanowienia, realizowanego poprzez świadome dokonywanie wyborów. Osoby, które są zdolne do samostanowienia o sobie, działają w sposób autonomiczny i potrafią same regulować własne zachowanie ${ }^{2}$.

Podstawowe czynniki stanowiące o możliwościach samostanowienia to wiek, kompetencje i zdolności oraz uwarunkowania zewnętrzne. Zgodnie z powszechnie przyjętą definicją „samostanowienie jest połączeniem umiejętności, wiedzy i przekonań, umożliwiającym jednostce autonomiczne postępowanie ukierunkowane na cel oraz poddawane samokontroli. Ważna jest świadomość posiadanych przez osobę możliwości oraz ograniczeń w połączeniu z wiarą we własne zdolności i skuteczność działań”3. Takie nastawienie wpływa na zwiększenie zdolności do kierowania własnym życiem i przyjęcia społecznej roli osoby dorosłej. Michael Lee Wehmeyer rozwinął tę definicję, określając zasadnicze cechy składające się na samostanowienie, m.in. autonomię, samoregulację, samorealizację ${ }^{4}$. W takim ujęciu nacisk położony jest na działania psychoedukacyjne mające na celu wyposażenie osoby z niepełnosprawnością w umiejętności, odpowiednią postawę oraz wiedzę, które są potrzebne do samostanowienia.

\section{Wychowanie ku samostanowieniu}

Kształcenie zdolności do samostanowienia oraz pracę nad stałym rozwojem związanych z tą cechą umiejętności i strategii postępowania należy

1 M. Jones, Teaching self-determination: empowered teachers, empowered students, „Teaching Exceptional Children" 1 (2006) 39, s. 12-17.

2 M. L. Wehmeyer, M. Agran, C. Hughes, Teaching self-determination to students with disabilities: Basic skills for successful transition, Baltimore 1998.

3 S. Field i in., A practical guide to teaching self-determination, Reston 1998, s. 2.

4 M. L., Wehmeyer, Self-determination and a strengths-based approach to intellectual disability, „Człowiek - Niepełnosprawność - Społeczeństwo” 2 (2012) 16, s. 25-26. 
rozpoczynać jak najwcześniej, traktując je jako długoterminowy cel w programie nauczania młodzieży z niepełnosprawnością ${ }^{5}$. Wendi D. Halloran ${ }^{6}$ określił samostanowienie jako podstawowy cel edukacyjny. Również Michael Lee Wehmeyer i Kathryn M. Kelchner ${ }^{7}$ twierdzą, że samostanowienie stanowi wynik kształcenia, i definiują je jako najważniejszy czynnik przyczynowy istniejący w życiu jednostki, wpływający na jej wybory i decyzje związane z jakością życia, wolny od ingerencji i nadmiernego wpływu z zewnątrz. Samostanowienie ma istotny wpływ na funkcjonowanie danej osoby - ludzie z jego niższym poziomem mają więcej problemów z przystosowaniem się, w większym zakresie izolują się od otoczenia, mają częstsze wahania nastroju oraz więcej problemów w komunikacji interpersonalnej.

Realizowane w USA projekty promujące nauczanie ukierunkowane na rozwijanie kompetencji do samostanowienia w znaczący sposób wpłynęły na rozwój metod nauczania oraz ujawniły złożoność problemów związanych $\mathrm{z}$ wychowaniem ku samostanowieniu ${ }^{8}$. W pedagogice specjalnej James E. Martin i Laura Huber Marshall ${ }^{9}$ zdefiniowali osoby zdolne do samostanowienia jako świadome tego, czego pragną, oraz wiedzące, jak to osiągnąć. Poczynając od świadomego określenia własnych potrzeb, osoby takie wybierają cele, po czym konsekwentnie dążą do ich osiągnięcia. Wymaga to rozpoznania własnych potrzeb, zajęcia określonej postawy wobec wybranych celów, oceny drogi ich realizacji, dostosowania działań oraz stworzenia własnego podejścia do rozwiązywania problemów. Działania takie pozwalają wypełniać role związane $\mathrm{z}$ dorosłością. Melissa Jones ${ }^{10} \mathrm{w}$ swych rozważaniach na temat pojęcia podmiotowości wskazuje na jego wieloznaczność, związaną ze zdolnością osoby do samostanowienia i przejęcia przez nią kontroli nad

5 B. Algozzine i in., Effects of interventions to promote self-determination for individuals with disabilities, „Review of Educational Research” 71 (2001), s. 219-226.

6 W. D. Halloran, Transition services requirement: Issues, implications, challenge, [w:] Recent advances in special education and rehabilitation, ed. R. C. Eaves, P. J. McLaughlin, Boston 1993, s. 214.

7 M. L. Wehmeyer, K. Kelchner, Perceptions of classroom environment, locus of control and academic attributions of adolescents with and without cognitive disabilities, „Career Development for Exceptional Individuals" 19 (1996), s. 24.

8 S. Field, M. D. Sarver, S. F. Shaw: Self-determination..., dz. cyt.; M. J. Ward, P. D. Kohler, Teaching self-determination: Content and process, [w:] On the road to autonomy: Promoting self-competence in children and youth with disabilities, ed. L. E. Powers, G. H. S. Singer, J. Sowers, Baltimore 1996, s. 33-36.

9 J. E. Martin, L. H. Marshall: Choice Maker: A comprehensive self-determination transition program, „Intervention in School and Clinic” 1995, s. 27-31.

10 M. Jones, Teaching self-determination..., dz. cyt., s. 12-17. 
222 własnym życiem, do świadomego uczestniczenia w indywidualnym programie nauczania (Individualized Education Program - IEP).

Zachowanie osoby zdolnej do samostanowienia ${ }^{11}$ cechuje: umiejętność dokonywania wyborów, podejmowania decyzji i rozwiązywania problemów, umiejętność wyznaczania celów i ich osiągania, zdolność do podejmowania ryzyka i zapewnienia sobie bezpieczeństwa, zdolność do samooceny, samokontroli oraz do korygowania własnego zachowania, umiejętność samokształcenia, niezależność, wiara w znaczenie działań podejmowanych $\mathrm{z}$ własnej inicjatywy, określana jako wewnętrznie umiejscowiona kontrola, a także pozytywne odniesienia wobec skuteczności podejmowanych działań i oczekiwanych rezultatów. Ważne znaczenie dla poziomu samostanowienia u osób z niepełnosprawnością intelektualną mają czynniki środowiskowe ${ }^{12}$ :

- miejsce zamieszkania (bardziej korzystne jest mieszkanie w domach chronionych czy niezależnych niż w dużych instytucjach);

- środowisko szkolne - istotne jest, czy stosowane programy nauczania i metody uwzględniają zindywidualizowane działania skoncentrowane na wspieraniu podejmowania decyzji i sprawowania kontroli nad swoim życiem;

- miejsce pracy - wyższy poziom samostanowienia jest skorelowany $\mathrm{z}$ dobraniem zindywidualizowanego stanowiska pracy oraz $\mathrm{z}$ wyższym wynagrodzeniem;

- opieka ze strony otoczenia - opieka o charakterze nadmiernie ochraniającym, stale kontrolującym i wyręczającym nie sprzyja rozwojowi kompetencji do samostanowienia. Podobnie negatywny charakter może mieć obowiązujący system prawny, np. instytucja ubezwłasnowolnienia;

- wielkość środowiska zamieszkania czy pracy - im mniejsza placówka, mniej współmieszkańców i osób z personelu, tym więcej okazji do dokonywania wyborów i tym wyższy poziom samostanowienia.

Oczywiście kompetencje do samostanowienia wiążą się z zachowaniami adaptacyjnymi i poziomem niepełnosprawności, jaki reprezentuje każda osoba. Ważne są także reprezentowane przez nią umiejętności, np. podejmowania decyzji czy rozwiązywania problemów.

11 B. Algozzine i in., Effects of interventions..., dz. cyt., s. 45-49; M. L. Wehmeyer, M. Agran, C. Hughes, Teaching self- determination..., dz. cyt., s. 21-27.

12 C. Antaki, W. M. Finlay, C. Walton, Choices for people with intellectual disabilities: Official discourse and everyday practice, "Journal of Policy and Practice in Intellectual Disabilities" 6 (2009) 4, s. 260-262. 

i niezależności

Program PACE został utworzony w 1986 roku przy National-Louis University, amerykańskiej uczelni istniejącej od 1886 roku. Przez wiele lat miał swoją siedzibę w Evanston w stanie Illinois, w roku 2006 został przeniesiony do pobliskiego ośrodka akademickiego w Skokie. PACE - Professional Assistant Center for Education, czyli Centrum Wspierania Edukacji Zawodowej, jest dwuletnim, płatnym, niedającym tytułu, ale certyfikowanym programem dla młodych dorosłych z niepełnosprawnością i problemami w uczeniu się, kształcącym w wielu aspektach niezależnego życia ${ }^{13}$.

Określany jako droga rozwoju, szans i niezależności ${ }^{14}$, program PACE jest liderem w dostarczaniu kompleksowych usług w zakresie kształcenia osób o specjalnych potrzebach edukacyjnych: umożliwia kontynuację edukacji oraz poznanie umiejętności koniecznych do rozpoczęcia niezależnego życia i uzyskania zatrudnienia ${ }^{15}$.

Według filozofii programu PACE, $w$ dużym stopniu opartej na pracach dr. Nicholasa Hobbsa (1915-1983) z George Peabody College (obecnie część Uniwersytetu Vanderbilta) ${ }^{16}$, do osiągnięcia prawdziwego sukcesu w życiu nie wystarczy sama praca - konieczne są także umiejętności organizacyjne, zainteresowania, uspołecznienie oraz odpowiednie wykorzystanie czasu wolnego. Zgodnie z holistycznym podejściem wszystkie te obszary są wzajemnie powiązane i współzależne z sukcesem w miejscu pracy; kiedy w życiu człowieka jest zachowana równowaga i doświadcza on sukcesu w pracy, $\mathrm{w}$ domu, $\mathrm{w}$ czasie wolnym, w nauce oraz w przyjaźni, czuje się spełniony i szczęśliwy ${ }^{17}$. Program stwarza przyjazne środowisko, w którym praca jest drogą do samorealizacji, zabawa jest nauką, a życie radością ${ }^{18}$.

13 L. Black: A future made possible for the learning-disabled, „Chicago Tribune” 2002, May 12, s. 8-10.

14 L. Rapisarda: Bridging the gap between school and employment. NLU PACE - niepublikowany skrypt 2002, s. 1.

15 C. Burns, The PACE Program - vocational training of persons witch complex learning disabilites, [w:] Rehabilitaion and education of persons with intellectual disabilities at thce turn of the 20th and 21 st centuries, ed. E. M. Kulesza, Warszawa 2007, s. 74-77.

16 B. Szczupał, Program PACE jako jedna z form rehabilitacji społecznej i zawodowej osób z niepetnosprawnościq intelektualna, [w:] Rehabilitacja społeczna i zawodowa osób z niepełnosprawnością intelektualna - od bierności do aktywności, red. J. Głodkowska, A. Giryński, Kraków 2006, s. 63-72.

17 L. Rapisarda: Bridging the gap..., dz. cyt., s. 4-10.

18 C. Burns, The PACE Program - vocational training..., dz. cyt., s. 74-79. 
W programie PACE zaadaptowano założenia Hobbsa do potrzeb słuchaczy wchodzących w dorosłość, zawierając jego filozofię ${ }^{19} \mathrm{w}$ następujących punktach:

- Życie jest po to, by żyć - każdy dzień, każda godzina w życiu jest ważna. Celem programu jest takie organizowanie teraźniejszości, by co dzień dostarczać każdemu z jego uczestników wielu udanych, pouczających doświadczeń życiowych.

- Zaufanie to podstawa - zaufanie pomiędzy słuchaczami, wychowawcami i kadrą programu jest konieczne, by móc nauczać i uczyć się z sukcesem. Gdy wzajemne relacje są oparte na zaufaniu, można osiągać nadzwyczajne i zadziwiające sukcesy.

- Czas jest sprzymierzeńcem - słuchacze są w wieku rozwojowym, mają do wykorzystania olbrzymi potencjał, często stłumiony przez rodzaj i stopień posiadanej niepełnosprawności. Program poprzez nauczanie i motywowanie do działania dostarcza wsparcia, wykorzystując właściwości okresu naturalnego rozwoju i wydłużając go. Zmiany te jednak nie mogą być wymuszane, a rozwój jest często nieoczekiwany i daje nadzwyczajne efekty.

- Kompetencje są decydujące - zdolność do wykonania zadań, bycia produktywnym i kreatywnym stanowi wartość człowieka w społeczeństwie. W programie PACE strategie kształcenia i metody wspomagania nauczania są łączone $\mathrm{z}$ wysiłkami, by przekonać słuchaczy o tym, iż mogą stać się kompetentni. Sukces w jednym obszarze działania często wspomaga sukces w innych dziedzinach, pozwalając w ten sposób słuchaczom wznieść się ponad ich własne ograniczenia.

- Niewłaściwe zachowanie może i powinno być kontrolowane - w programie PACE osoby te są włączone w życie pełnosprawnych rówieśników w celu ciągłego rozwoju umiejętności społecznych, są odpowiedzialne za własne zachowanie i kształtują je metodą prób i błędów, otrzymując pełne wsparcie podczas całego programu.

- Inteligencji można nauczyć - kompetencje kognitywne słuchaczy mogą zostać rozwinięte, inteligencja rozwija się i osiąga coraz wyższy stopień, pomagając w podejmowaniu decyzji w życiu. Rolą programu jest dostarczenie jego słuchaczom narzędzi do zaangażowania myślenia abstrakcyjnego w celu rozwiązywania problemów.

19 L. Rapisarda: Bridging the gap..., dz. cyt., s. 4-10. 
- Nad uczuciami można zapanować - słuchacze są poddawani presji, a stawiane im wymagania wywołują w nich różne uczucia i emocje. Według filozofii PACE uczuciami należy się dzielić $\mathrm{z}$ innymi w celu ich zdefiniowania i właściwego radzenia sobie z nimi. Program dostarcza wielu okazji dla ćwiczenia umiejętności niezbędnych w budowaniu poczucia własnej godności i tożsamości.

- Grupa jest ważna - stanowi główne źródło rozwoju umiejętności oraz wsparcia dla słuchaczy, umożliwiając im współdziałanie z rówieśnikami na wielu poziomach. Bliskie relacje $\mathrm{z}$ otoczeniem, pochwały i wzmocnienie pozytywne, szacunek, tolerancja, konstruktywna krytyka i zainteresowanie okazywane słuchaczom - oddają sens ducha wspólnotowego i przynależności do grupy.

- Rozwiązanie problemu jest bardziej efektywne - gdy zawodzą możliwości zapanowania nad sytuacją krytyczną, objawiającą się niewłaściwym zachowaniem, lepsze efekty niż modyfikacja takiego zachowania daje rozwiązanie problemu - pokazuje słuchaczom możliwości kontrolowania własnego zachowania, pomagając im $\mathrm{w}$ osiąganiu niezależności. „Życie jest pełne problemów, ale wszystkie problemy mają rozwiązania" - to jedna z podstawowych zasad PACE.

- Należy doświadczać radości - umiejętność cieszenia się, odczuwania radości jest ważna dla dobrostanu każdej osoby; doświadczanie przez słuchaczy radości każdego dnia jest działaniem terapeutycznym. Słuchacze programu mieszkają w realnym świecie, doznając wielu radosnych sytuacji w społeczności, w której żyją i się uczą.

Każdego roku do programu PACE ${ }^{20}$ przyjmowana jest grupa około 20-25 osób z niepełnosprawnością lub z zaburzeniami psychicznymi (z zespołem Downa, Williamsa, autyzmem czy dwubiegunowymi zaburzeniami afektu), spełniających określone kryteria: wiek od 18 do 30 lat oraz ukończona szkoła średnia; konkretne problemy z uczeniem się (trudności w poznawaniu, rozumieniu i przetwarzaniu informacji); wyniki testów IQ w granicach 70-90, mniej punktów na testach zdolności poznawczej; zainteresowanie pracą, emocjonalna stabilność oraz zdolność do współpracy $\mathrm{w}$ grupie i aktywnego uczestnictwa $\mathrm{w}$ działaniach programu; wsparcie ze strony rodziców, w pełni popierających cele i filozofię programu ${ }^{21}$.

20 PACE Application Information: http://www.nl.edu/paceatnlu/ (dostęp: 02.01.2016.)

21 L. Rapisarda: Bridging the Gap..., dz. cyt., s. 10-12. 
Uczestnicy programu PACE mieszkają w kampusie uniwersyteckim, wraz z nimi mieszkają także dwaj etatowi pracownicy programu, udzielający pomocy w planowaniu zadań i przy rozwiązaniu problemów ${ }^{22}$. Mają dostęp do wszystkich uniwersyteckich udogodnień - pracowni komputerowych, obiektów sportowych i rekreacyjnych, stołówki, usług finansowych i medycznych, biblioteki, teatru i innych ${ }^{23}$. Wśród pracowników programu najliczniejszą grupę stanowią osoby z profesjonalnym przygotowaniem w dziedzinie pedagogiki specjalnej; są również specjaliści w dziedzinach rehabilitacji zawodowej, pracy socjalnej oraz trenerzy programu ${ }^{24}$.

Program PACE łączy nauczanie (zarówno grupowe, jak i indywidualne) z aktywnością we wszystkich obszarach życia słuchaczy, zawierając w sobie takie komponenty, jak: przygotowanie kariery, nauka, umiejętności życiowe, socjalizacja ${ }^{25}$. Nauczanie w czterech powyższych obszarach jest traktowane jako najważniejsze narzędzie kompleksowego wspierania rozwoju i zdobywania wiedzy - przy założeniu, że najlepsze efekty osiąga się, łącząc ściśle proces nauczania $\mathrm{z}$ działaniem i wyznaczaniem celów.

Przygotowanie kariery ${ }^{26}$ - w ramach tego komponentu programu słuchacze uczestniczą w ponad 1000 godzin zajęć w ciągu dwóch lat (trzy dni w tygodniu po sześć godzin dziennie) w ramach stażu wewnętrznego w minimum trzech miejscach pracy. Istnieją różne możliwości wyboru zawodu i przygotowania ścieżki kariery, ze zindywidualizowanym nauczaniem pod kątem pracy, udziałem w seminarium stażowym oraz innych dodatkowych kursach i szkoleniach. Słuchacze programu mogą odbywać staże zgodnie z ich zainteresowaniami i umiejętnościami - do wyboru mają następujące zajęcia: opieka nad dzieckiem, opieka nad osobami starszymi, praca w usługach gastronomicznych, prace biurowe, magazynowe oraz transportowe, pomoc domowa, opieka nad zwierzętami, pomoc szpitalna. Nauczanie odbywa się poprzez praktykę i zdobywanie doświadczenia, które wymaga odpowiedniego pokierowania słuchacza (każdy ma wyznaczonego instruktora pracy). Słuchacz pierwszego roku pracuje w dwóch miejscach, po piętnaście tygodni w każdym. Jest to czas przeznaczony na zbadanie ogólnych umiejętności i zdefiniowanie zainteresowań oraz predyspozycji zawodowych.

22 L. Black: A future..., dz. cyt., s. 8-10.

23 C. Burns, The PACE Program - vocational training..., dz. cyt., s. 74-79.

24 D. Makos, PACE Program. Wyższa uczelnia dla upośledzonych, „Bardziej Kochani” 1 (2009), s. 34-41.

25 B. Szczupat: Program PACE..., dz. cyt., s. 63-72.

26 C. Burns, The PACE Program - vocational training..., dz. cyt., s. 74-79. 
Na drugim roku słuchacze wybierają jeden obszar zawodowy i skupiają się na nim przez cały rok szkolny. Osoby uczestniczące w programie samodzielne używają środków transportu publicznego ${ }^{27}$.

Nauka ${ }^{28}$ odbywa się przez dwa dni w tygodniu (w pozostałe trzy dni jest szkolenie zawodowe w ramach stażu wewnętrznego). Zajęcia są tak przygotowane, by mogły spełnić oczekiwania słuchaczy programu, a ich forma umożliwia zapoznanie się z tematem, zdefiniowanie pojęcia i zrozumienie jego współzależności z prawdziwym życiem. Kładziony jest nacisk na rozwijanie zdolności poznawczych, rozwój strategii rozwiązywania problemów, planowanie oraz systematyczne wykonywanie tygodniowych zadań i obowiązków. Osoby szczególnie uzdolnione mają możliwość uczęszczania na wybrane zajęcia na uniwersytecie jako wolni słuchacze. Seminarium stażowe, uzupełniające szkolenie w miejscu pracy, podczas I roku nauki skupia się na szkoleniu podstawowym, transporcie, wyznaczaniu celów, kwestii odpowiedzialności, podstawowych umiejętnościach w pracy oraz konstruktywnej krytyce. Seminarium stażowe na II roku koncentruje się bardziej na umiejętnościach społecznych, przygotowaniu do zawodu i aktywnego poszukiwania pracy (samodzielne poszukiwanie pracy, pisanie życiorysu oraz przygotowanie się do rozmowy kwalifikacyjnej). Trening zawodowy jest tak zaprojektowany, aby zachęcał do rozwoju ogólnych umiejętności, zdobycia pogłębionej wiedzy na temat pracy oraz zaplanowania ścieżki zatrudnienia ${ }^{29}$.

Umiejętności życiowe ${ }^{30}$ - zajęcia $\mathrm{z}$ tego obszaru szkolenia są wspomagane przez cotygodniowe nauczanie (zajęcia w małych grupach oraz indywidualne, prowadzone przez instruktorów programu PACE) w obszarach takich, jak: umiejętności samodzielnego życia, gospodarowanie pieniędzmi, zarządzanie czasem, korzystanie z transportu publicznego itp.

Socjalizacja - integralna część programu - obejmuje teorię i praktykę umiejętności społecznych, kwestie współdziałania i rozwiązywania problemów interpersonalnych, udział w działalności wspólnoty oraz kształtowanie umiejętności planowania i niezależnego wyboru. Program oferuje różne możliwości poszerzania umiejętności poznawczych - podczas pracy,

27 L. Rapisarda, Bridging the gap..., dz. cyt., s. 4-10; B. Szczupał, Program PACE.., dz. cyt., s. 63-72.

28 C. Burns, The PACE Program - vocational training..., dz. cyt., s. 74-79.

29 L. Rapisarda, Bridging the gap..., dz. cyt., s. 15-16; B. Szczupał: Program PACE..., dz. cyt., s. 63-72.

30 D. Makos, PACE Program..., dz. cyt., s. 34-41. 
228 zajęć sportowych oraz spotkań towarzyskich. Uczestniczenie w codziennym życiu środowiska uczelnianego oraz praca w ramach stażu dostarczają wielu okazji do spotkań z rówieśnikami oraz personelem programu, pomagają w rozwijaniu umiejętności społecznych i przygotowują do samodzielności ${ }^{31}$.

Każdy dzień słuchaczy programu PACE jest wypełniony zajęciami: trzy dni w tygodniu trwa szkolenie w ramach stażu wewnętrznego, dwa dni $\mathrm{w}$ tygodniu są poświęcone na naukę, zaś wieczory oraz weekendy przeznaczone są na rozrywkę i aktywność w ramach czasu wolnego. Zgodnie z filozofią programu ważna jest każda godzina każdego dnia, a doświadczenia zdobyte podczas zajęć czasu wolnego są okazją do podejmowania decyzji i rozwiązywania problemów. Program zapewnia słuchaczom zajęcia przygotowujące ich do wyzwań i zadań czekających w dorosłym świecie ${ }^{32}$. Na zakończenie dwuletniego programu PACE jego absolwenci otrzymują świadectwa ukończenia programu oraz do dwunastu zaświadczeń o przyswojonych umiejętnościach.

Do wybranych absolwentów skierowany jest program PACE Przejście (Przejście do Niezależnego Życia - PACE Transition Program) ${ }^{33}$, który pozwala na pozostanie w obecnym, znajomym, bezpiecznym środowisku społecznym. Uczestnicy programu przenoszą się do wynajętych mieszkań wraz z innymi słuchaczami programu Przejście. Z pomocą instruktora załatwiają wszelkie sprawy (od płacenia rachunków przez gotowanie po porządki); zaczynają aktywne poszukiwanie zatrudnienia. Program trwa przez około trzy lata (ze stopniowym zmniejszaniem wsparcia ze strony PACE) i koncentruje się na czterech obszarach: samodzielnym mieszkaniu, pracy, kursach i seminariach jako formach kontynuowania trwającej przez całe życie nauki oraz rozwoju kontaktów społecznych (m.in. poprzez włączanie się w życie większej społeczności, uczestnictwo w grupach społecznych, opiekę nad nowymi uczestnikami programu PACE) $)^{34}$. W ten sposób absolwenci programu PACE kontynuują swój rozwój.

31 L. Rapisarda, Bridging the gap..., dz. cyt., s. 15-16; B. Szczupał: Program PACE.., dz. cyt., s. 63-72.

32 L. Rapisarda, Bridging the gap..., dz. cyt., s. 15-16; B. Szczupat: Program PACE..., dz. cyt., s. 63-72.

33 D. Makos, PACE Program..., dz. cyt., s. 34-41; L. Rapisarda: Bridging the gap..., dz. cyt., s. $15-16$.

34 L. Rapisarda: Bridging the gap..., dz. cyt., s. 15-16; B. Szczupał: Program PACE..., dz. cyt., s. 63-72. 
Sukces, jaki osiąga znaczna część absolwentów programu PACE, dowodzi, że kształtowanie zdolności do samostanowienia wymaga tworzenia jak największej ilości możliwości, dzięki którym osoba z niepełnosprawnością będzie mogła wykazać swoją wolę oraz sprawdzić w praktyce nabyte kompetencje kształtowania swojej rzeczywistości. Przedstawiony program jest wartościowym uzupełnieniem wielu form integracji społeczno-zawodowej osób z niepełnosprawnością. Należy podkreślić, że niepełnosprawność stanowi naturalną część ludzkiego doświadczenia i nie pomniejsza praw tych osób do: niezależnego życia w społeczeństwie, samostanowienia o swoim losie, dokonywania wyborów, wykonywania zawodu oraz pełnej inkluzji i integracji ze społecznością w każdym zakresie (ekonomicznym, politycznym, społecznym, kulturalnym oraz edukacyjnym). Niepełnosprawność jest tylko częścią człowieka i nie określa go całkowicie - dysponuje on bowiem także całym profilem osobistych zdolności i możliwości. Z tego punktu widzenia należy postrzegać osoby z niepełnosprawnością przez pryzmat ich możliwości oraz potrzeb, stanowiących fundament, na którym można rozwijać kompetencje wpływające na zdolność do ich samostanowienia oraz umożliwiające im osiągnięcie jak największej niezależności.

Self-determination and socio-professional integration of adults with disabilities based on the example of the use of the Professional Assistant Center for Education (PACE) in the USA

Education towards self-determination is a relatively new direction of activities towards young people with disabilities. Self-determination can be understood in many ways. As a construct, it has two basic meanings: (1) the rights of a collective group, usually citizens of a country, to self-governance, and (2) a personal construct referring to having control over one's life. Many people assume that the presence of an intellectual disability precludes a person from becoming self-determined. In this article I discuss the PACE program as an example of education to self-determination and independence of people with various disabilities. Among others, I am presenting assumptions, criteria for selection of participants, social and vocational rehabilitation carried out in the framework of the PACE and its effectiveness.

Keywords: self-determination, intellectual disabilities, autonomy 
Samostanowienie i integracja społeczno-zawodowa dorosłych osób z niepełnosprawnością na przykładzie zastosowania Programu Centrum Wspierania Edukacji Zawodowej (PACE) w USA

Wychowanie ku samostanowieniu jest stosunkowo nowym kierunkiem oddziaływania wobec młodych osób z niepełnosprawnością. Samostanowienie może być rozumiane na wiele sposobów. Jako pewien konstrukt ma dwa podstawowe znaczenia: (1) prawo pewnej zbiorowości, zwykle obywateli kraju do samorządności, (2) konstrukt osobisty dotyczący sprawowania kontroli nad własnym życiem. Wielu ludzi zakłada, że obecność niepełnosprawności intelektualnej wyklucza możliwość bycia osobą samostanowiącą. W artykule omawiam Program PACE jako przykład wychowania ku samostanowieniu i niezależności osób z różnymi niepełnosprawnościami. Przedstawiam m.in. założenia, kryteria doboru uczestników, rehabilitację społeczno-zawodową realizowana w ramach PACE oraz jego efektywność.

Słowa kluczowe: samostanowienie, niepełnosprawność intelektualna, autonomia

\section{Bibliografia}

Algozzine B. i in., Effects of interventions to promote self-determination for individuals with disabilities, „Review of Educational Research” 71 (2001), s. 219-277.

Antaki C., Finlay W. M., Walton C., Choices for people with intellectual disabilities: Official discourse and everyday practice, „Journal of Policy and Practice in Intellectual Disabilities" 6 (2009) 4, s. 260-266.

Black L., A future made possible for the learning-disabled, „Chicago Tribune” 2002, May 12, s. 8-10.

Brigham M., Kauffman J. M., Mcgee K., Enabling or disabling? Observations on changes in special education, „Phi Delta Kappa” vol. 85 (2004) 8, s. 613-620.

Brinckerhoff L. C., McGuire J. M., Shaw S. E., Postsecondary education and transition for students with learning disabilities, Austin 2002.

Burns C., The PACE Program - vocational training of persons witch complex learning disabilites, [w:] Rehabilitaion and education of persons with intellectual disabilities at thce turn of the 20th and 21 st centuries, ed. E. M. Kulesza, Warszawa 2007, s. 74-77.

Carter E. W. i in., Self-determination skills and opportunities of transition-age youth with emotional disturbance and learning disabilities, „Exceptional Children” 3 (2006) 72 , s. 333-346.

Field S. i in., A practical guide to teaching self-determination, Reston 1998.

Field S., Sarver M. D., Shaw S. F., Self-determination: a key to success in postsecondary education for students with learning disabilities, „Remedial and Special Education” 6 (2003) 24, s. 339-349. 
Halloran W. D., Transition services requirement: Issues, implications, challenge, [w:] Recent advances in special education and rehabilitation, ed. R. C. Eaves, P. J. McLaughlin, Boston 1993, s. 210-224.

Harth R., Burns C., A follow-up of graduates of the PACE program: the first fifteen years, NLU PACE - niepublikowany skrypt (sprawozdanie z badań) 2002.

Jones M., Teaching self-determination: empowered teachers, empowered students, „Teaching Exceptional Children” 1 (2006) 39, s. 12-17.

Makos D., PACE Program. Wyższa uczelnia dla upośledzonych, „Bardziej Kochani” 1 (2009), s. 34-41.

Martin J. E., Marshall L. H., Choice Maker: A comprehensive self-determination transition program, „Intervention in School and Clinic” 30 (1995), s. 147-156.

PACE - Professional Assistant Center for Education - www.nl.edu/pace (dostęp: 02.01.2016.)

Quinn G., Degener T., Human rights and disability. The current use and future potential of United Nations human rights instruments in the context of disability, New YorkGeneva 2002.

Rapisarda L., Bridging the gap between school and employment, NLU PACE - niepublikowany skrypt, 2002.

Szczupał B., Program PACE jako jedna z form rehabilitacji społecznej i zawodowej osób z niepełnosprawnościa intelektualna, [w:] Rehabilitacja społeczna i zawodowa osób z niepełnosprawnością intelektualna - od bierności do aktywności, red. J. Głodkowska, A. Giryński, Kraków 2006, s. 63-72.

Ward M. J., Kohler P. D., Teaching self-determination: Content and proces, [w:] On the road to autonomy: Promoting self-competence in children and youth with disabilities, ed. L. E. Powers, G. H. S. Singer, J. Sowers, Baltimore 1996, s. 275-290.

Wehmeyer M. L., Self-determination and a strengths-based approach to intellectual disability, „Człowiek - Niepełnosprawność - Społeczeństwo” 2 (2012) 16, s. 23-34.

Wehmeyer M. L., Agran M., Hughes C., Teaching self-determination to students with disabilities: Basic skills for successful transition, Baltimore 1998.

Wehmeyer M. L., Kelchner K., Perceptions of classroom environment, locus of control and academic attributions of adolescents with and without cognitive disabilities, „Career Development for Exceptional Individuals" 19 (1996), s. 15-29.

Williams J. M., O'Leary E., What we've learned and where we go from here, "Career Development for Exceptional Individuals" 24 (2001), s. 51-71. 